FITRAH Jurnal Kajian Ilmu-ilmu Keislaman

Vol. 02 No. 2 Desember 2016

e-ISSN : 2460-2345, p-ISSN: 2442-6997

Web: jurnal.iain-padangsidimpuan.ac.id/index.php/F

\title{
PENDIDIKAN ROHANI DALAM AL-QURAN
}

\author{
DR. Tarmizi, M.Pd.
}

A Lecturer in State University for Islamic Studies North Sumatera, Medan. Email: abdurrahman.srg@gmail.com

\begin{abstract}
Spiritual education is an education to teach the spiritual aspect human to improve their relationship with Allah through the worship and humble and obedient to Him and submit to His manhaj. The spiritual aspect is the soft elements with the existence as the main requirement for the biological processes associated with consciousness, the mind and the will; encompassing the soul, mind, heart, and lust. Spiritual education is done through Dzikrullah, Prayer, Fasting, Tazkiyah, Muraqabah, and Ridha.
\end{abstract}

Keywords: Education, Spiritual, al-Qur'an

\begin{abstract}
Abstrak
Pendidikan rohani ialah pendidikan yang bertujuan untuk mengajarkan pada aspek rohaniah dalam diri manusia sebagai upaya memperbaiki hubungannya dengan Allah Swt melalui jalan menyembah dan merendah kepada-Nya serta taat dan tunduk kepada manhaj-Nya. Aspek rohaniah itu ialah unsur-unsur halus yang keberadaannya merupakan syarat utama bagi proses hayati yang berhubungan dengan kesadaran, pikiran dan kemauannya; yakni mencakup jiwa, akal, hati, dan nafsu. Pendidikan rohani itu dilakukan melalui Dzikrullah, Shalat, Puasa, Tazkiyah, Muraqabah, dan Ridha.
\end{abstract}

Kata Kunci: Pendidikan, Rohani, al-Qur'an.

\section{PENDAHULUAN}

Al-Quran merupakan sumber ajaran Islam yang pertama dan yang paling pokok juga sebagai dalil dari berbagai hukum-hukum agama. Al-Quran menurut bahasa berarti bacaan. Adapun menurut istilah, al-Quran adalah kalam Allah yang diturunkan kepada nabi Muhammad Saw dengan berbahasa arab yang dinukil kepada dengan cara yang mutawatir, merupakan ibadah membacanya, tertulis di berbagai mushaf dimulai dengan surat al-Fatiha dan ditutup dengan surat an-Nas. Seluruh suratnya merupakan mu jizat walaupun surat yang paling pendek daripadanya agar menjadi hujjah bagi Rasulullah Saw bahwa beliau 
merupakan utusan Allah dan agar menjadi undang-undang dan petunjuk bagi manusia. Al-Quran menjadi sumber ajaran paling utama dalam agama Islam dalam berbagai aspek kehidupan termasuk pendidikan.

Pendidikan merupakan hal yang sangat penting dalam menciptakan generasi Islam yang tangguh dan berakhlak mulia. Paradigma pendidikan dalam Islam, pembinaan tidak hanya tertuju kepada akal dan jasmani tapi juga tertuju kepada aspek rohani manusia dengan menguatkan hubungannya dengan Tuhan. Paradigma ini tidak ditemukan dalam konsep pendidikan Barat yang hanya mengutamakan pembinaan rasional dan empiris. Oleh sebab itu dalam makalah yang sederhana ini akan dibahas mengenai pendidikan rohani sebagaimana yang tertuang dalam al-Quran dengan menggunakan penafsiran tematik. Penafsiran tematik adalah penafsiran yang membahas suatu tema tertentu menurut alQuran secara mendetail. Langkah-langkahnya diawali dengan memilih topik yang dikaji, kemudian membatasi atau mencari berbagai ayat yang terkait dengan tema dengan metode induktif, selanjutnya menyusun ayat tersebut dan mengkaji kesesuainnya dengan topik bahasan, setelah itu dianalisi maksudnya dan tekstualnya dengan berbagai pendapat ulama dan hadis-hadis Nabi sebagai penguat. ${ }^{1}$

Disamping itu penjelasan tafsir tematik ini akan dikuatkan juga dengan hadis-hadis Nabi Saw dan berbagai pendapat ulama sehingga dapat lebih memperjelas tema yang sedang dikaji di sini. Diharapkan dengan metode ini jelas bagi kita bagaimana pendidikan rohani sebagaimana yang tertuang dalam al-Quran al-Karim pedoman umat manusia.

\section{Defenisi Pendidikan Rohani}

Sebelum lebih jauh memaparkan pendidikan rohani, maka terlebih dulu di sini didefeniskan maksud dari pendidikan rohani sehingga dapat membantu dalam memperjelas paparan isi makalah ini. Menurut Kamus Besar Bahasa Indonesia, pendidikan dapat diartikan sebagai proses perubahan sikap dan tata laku seseorang atau kelompok orang dalam usaha mendewasakan manusia melalui upaya pengajaran dan latihan, proses, perbuatan dan cara mendidik. ${ }^{2}$. Pada hakekatnya pendidikan adalah usaha orang tua atau generasi tua untuk mempersiapkan anak atau generasi muda agar mampu hidup secara mandiri

\footnotetext{
hlm.141-202

${ }^{1}$ Samir Abdurrahman Rasyuni, Manhaj at-Tafsir al-Maudhu`i (Suria: Dar al-Multaqa, 2009),

${ }^{2}$ Dinas P \& K, Kamus Besar Bahasa Indonesia, (Jakarta: Balai Pustaka, 2003), hal. 204
} 
dan mampu melaksanakan tugas-tugas hidupnya dengan sebaik-baiknya. Orang tua atau generasi tua memiliki kepentingan untuk mewariskan nilai, norma hidup dan kehidupan generasi penerus.

Ki Hajar Dewantara mengatakan:"mendidik ialah menuntun segala kekuatan kodrat yang ada pada anak-anak agar mereka sebagai manusia dan sebagai anggota masyarakat dapat mencapai keselamatan dan kebahagiaan yang setinggi-tingginya. ${ }^{3}$ Disebutkan di dalam Undang-Undang Dasar Republik Indonesia Nomor 2 Tahun 1989 tentang Sistem Pendidikan Nasional, pendidikan adalah "usaha sadar untuk menyiapkan peserta didik melalui kegiatan bimbingan, pengajaran atau latihan bagi peranannya di masa yang akan datang. ${ }^{4}$ Tegasnya, pendidikan adalah upaya dan bantuan generasi tua untuk mengembangkan segala aspek dan potensi yang ada pada peserta didik untuk mewujudkan tujuan pendidikan.

Selanjutya perlu difahami maksud ruh. Ruh adalah sebab kehidupan, ia juga nama bagi nafsu karena nafsu adalah bagian dari ruh juga. Karena nafsu juga sumber kehidupan anggota badan dan fa'al tubuh. Adapun dari segi istilah ruh dapat didefenisikan :

1. Ruh adalah sumber kehidupan di badan. Karena syarat kehidupan badan ini adalah meratanya ruh padanya seperti meresapnya air mawar pada mawar. ${ }^{5}$

2. Ruh adalah udara yang keluar masuk di rongga badan manusia, ia menurut kaum tabib kuno adalah jisim yang seperti uap yang mencul dari jantung yang menyebar melalui urat-urat dan saraf ke seluruh bagian tubuh. Menurut Decart dan pengikutnya ${ }^{6}$. Ruh adalah bagian darah yang halus yang mengalir dari jantung ke otak kemudian dari otak menyebar melalui berbagai urat syaraf ke seluruh badan. ${ }^{7}$ Dari sini dapat dipahami bahwa ruh adalah jisim yang halus yang memiliki berat dan demensi dan ia tidak menetap.

3. Ruh manusia adalah esensi halus manusia yang mengetahui dan yang memahami, yang mengontrol ruh hewani, turun dari alam kesatuan dimana

${ }^{3}$ Aulia Reza Bastian, ReformasiPendidikan, (Yogyakarta: Lappera Pustaka Utama, 2002), hlm.11-12

${ }^{4}$ Departemen Pendidikan dan Kebudayaan , op.cit., hlm.6

${ }^{5}$ At-Tahanuwi, KasyfuIstilah al-Funun (Cairo: Dar al-Fikri, tt) jilid. 3, hlm. 26.

${ }^{6}$ Rini Decart, Maqal an al-Manhaj, hal.152 (Alihbahasa : Mahmud Muhammad alKhudhairi, Cairo: al-Hai ah al-Mishriyah lil kitab al-Ammah, 1985).

${ }^{7}$ Ibid., hlm.26. 
akal tidak mampu untuk mengetahui hakikatnya ruh ini, bisa jadi ia mengalami pembaharaun dan kadang ruh menjadi tabiat di badan. ${ }^{8}$

4. Ruh sebagaimana yang diungkapkan oleh Abu al-barakat al-Baghdadi, ia tersohor menentang keras faham Aristitoteles dan aliaran skolastik. Defenisi ruh manusia menurutnya memiliki ciri khas sendiri ia mengungkapkan bahwa nafsu adalah kekuatan yang menempati badan yang beraksi padanya dan dengannya terwujud berbagai perbuatan dan gerak yang beraneka macam dalam berbagai waktu dan tujuan didasari oleh perasaaan dan pengetahuan yang istimewa yang dengannya terwujud kesempuranan manusia dan dengannya pula manusia terpelihara. ${ }^{9}$

5. Imam al-Ghazali dan para ahli hakikat, ulama-ulama kalam serta kebanyakan kaum sufi dan kaum filosof menyatakan ruh adalah esensi yang murni bukan jisim dan tidak memiliki sifat jisim, terkait dengan badan dengan kaitan yang fungsinya mengatur dan menggerakkan, bukan kaitan yang sifatnya hubungan bagian dengan kesatuan, bukan juga kaitan antara tempat dan yang menempati, ia benar kekal setelah rusaknya badan serta mengetahui halhal yang global dan terinci. ${ }^{10}$

6. Pendapat lain menyatakan ruh sebagaimana yang diungkapkan oleh filsafat materialistik. Menurut mereka ruh ialah perihal yang skunder jika dikaitkan dengan tabiat, ruh menurut kaum materialistik kuno adalah bagian terbesar dari akal di dalam diri yang menguasai seluruh jasad. Pada abad 17 dan 18 sebagain kaum materialistik seperti Huwaiz, Luk Lamitri berasumsi bahwa ruh adalah hanya sekedar bentuk bagi pengatahuan yang inderawi. Begitupula aliran materialistik dealektika tidaklah menyandarkan suatu yang sifatnya ruh kepada hasil perasaan yang sederhana, sebagaimana ia juga menolak gambaran bahwa ruh adalah sesuatu yang beridiri terbebas dari materi. Segala yang ruhani adalah fungsi dari materi dalam bentuknya bagiannya yang tertinggi. ${ }^{11}$

${ }^{8}$ Al-Jurjani, At-Ta rifat, (Mesir: Musthafa al-Halabi, 1938), hlm.34

${ }^{9}$ Yahya Huwaidi, Dirasat fi 'ilmi al-Kalamwa al-Falsafah al-Islamiyah (Mesir: Dar atsTsaqafah, 1980), hlm. 258.

${ }^{10}$ Abdur Rahman al-Burquni, al-Hadiyah as-Sa idiyah fi al-Hikmahath-Thabi iyah, (Cairo: alManar al-Islamiyah, 1222 H), hlm. 208

11 Team Ilmuan dan akademisi Universitas Soviet, al-Mausu'ah al-Falsafiyah, (terjemahan: Samir Karam, Beirut: Dar at-Thali ah, 1981), cetakan. IV, hlm. 231. 
Adapun rohani merupakan isim nisbat yang berfungsi mengaitkan sesuatu kepada yang lainnya. Jadi rohani adalah suatu yang dikaitkan dengan roh yang bermakna susunan badan halus, unsur-unsur halus atau gaib yang keberadaannya merupakan syarat utama bagi proses hayati, lebih-lebih yang berhubungan dengan kesadaran, pikiran dan kemauannya. Unsur-unsur halus tersebut mencakup : jiwa, akal, hati dan nafsu. ${ }^{12}$ Jadi pendidikan rohani sebagaimana yang dijelaskan oleh Abdul Halim Mahmud adalah pendidikan yang bertujuan untuk mengajarkan pada roh ini bagaimana memperbaiki hubungannya dengan Allah Swt melalui jalan menyembah dan merendah kepada-Nya serta taat dan tunduk kepada manhaj-Nya. ${ }^{13}$

Setelah ada kejelasan tentang maksud pendidikan ruh, maka dalam sub bab selanjutnya dibahas mengenai pendidikan rohani seperti tertuang dalam alQuran. Secara tegas al-Quran tidak menyebutkan pendidikan rohani namun hal ini dapat dipahami dari konteks ayat. Sebagaimana dijelaskan sebelumnya bahwa pendidikan rohani adalah pendidikan yang membenahi roh hamba dalam hal hubungannya dengan Allah Swt. Jadi pendidikan rohani membahas hablum minallah atau ibadah yang bersifat vertikal. Ibadah vertikal yang terhubung kepada Allah adalah seperti zikir, shalat, puasa, haji, ridha, muraqabah, tazkiyah dan lain sebagainya. Inilah yang akan dibahas selanjutnya.

\section{Pendidikan Rohani Dalam al-Quran}

Sebelum dipaparkan mengenai pendidikan rohani dapat dijelaskan dulu term ruh dalam al-Quran. Term ruh di dalam al-Quran terdapat pada 25 tempat. Kata ini lebih sedikit disebutkan dari kata nafsu. Teks-teks ini menunjukkan bahwa ruh adalah ciptaan Allah Swt dan bahwasanya ajalnya dan rezekinya telah ditentukan. Ia senantiasa disandarkan kepada Allah Swt. Ia sering ditujukan untuk menunjukkan kepada kehidupan, tidak pernah sekalipun ia menunjukkan kepada badan saja atau menunjukkan kepada kata badan dan nafsu sekaligus. Walaupun demikian kata ini memiliki enam arti:

1. Kata ruh muncul memiliki arti ciptaan Allah Swt. Inilah yang menjadi pendapat Ibnu Qayyim yang mengatakan bahwa sesungguhnya yang menciptakannya dan menjadikannya telah membentuk rupa ruh dan yang menentukan kejadian lahir, ajalnya, dan amal-amalnya, ia telah mewujudkan rupa-rupa tersebut dari materinya kemudian

${ }^{12}$ M. Shodiq, Kamus Istilah Islam, (Jakarta : C.V. Sientarama, 1998), hlm. 83

${ }^{13}$ Abdul Halim Mahmud, Pendidikan Ruhani, (Jakarta : Gema Insani Press, 2000), hlm. 70 
mengembalikannya semula. Ruh tidaklah diciptakan dengan ciptaan yang menetap kemudian ia terus berkesinambungan eksis hidup dan mengetahui, berakal dan lainnya di satu tempat ${ }^{14}$, ayat-ayat Quran merupakan sebaikbaik saksi atas hal ini. Seperti firman Allah Swt:

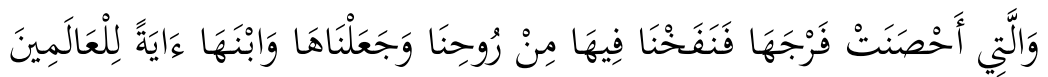
Artinya: "dan wanita yang memelihara kemaluannya kemudian Kami tiupkan kepadanya dari ruh Kami dan Kami jadikan ia dan anaknya sebagai tanda bagi semesta alam",(QS: al-Anbiya: 91).

Peniupan ruh di jasad maksudnya adalah menghidupkannya. ${ }^{15}$ Allah Swt berfirman:

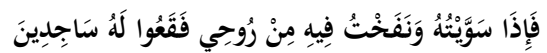

Artinya: "Dan ketika Aku sempurnakan kejadiannya dan Aku tiupkan kepadanya dari Ruhku maka tersungkurlah kamu sujud kepadanya", (QS : al-Hijir : 29). Maksudnya: ketika Allah menciptakannya. Begitu juga firman Allah Swt:

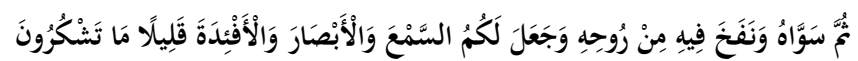

Artinya: "Kemudian Dia menyempurnakan kejadiannya dan meniupkan kepadanya dari ruh Nya dan menjadikan kamu pendengaran, penglihatan serta hati, amatlah sedikitlah kamu bersyukur",(QS: asSajadah: 9).

Penyandaran ruh kepada Zat Allah Swt menunjukkan bahwa dia adalah makhluk yang menakjubkan tidak ada yang mengetahui hakikatnya selain Allah Swt. ${ }^{16}$ Demikian pula firman Allah Swt:

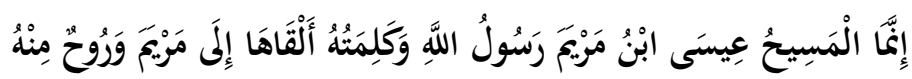

Artinya: "Sesungguhnya al-Masih Isa bin Maryam adalah utusan Allah dan kalimatNya di sampaikannya kepada Maryam begitu juga ruh dariNya", (QS: an-Nisa: 171).

Boleh jadi maksud dari firman Allah Swt yang bermakna dan ruh dariNya mencakup dua hal yaitu ia tercipta dengan tiupan malaikat yang disebut dengan ruh atau dengan ruh qudus kepada ibunya dengan tiupan seperti pembuahan yang terjadi dengan hubungan suami istri. Ia

${ }^{14}$ Ibnu al-Qayyim, Kitabar-Ruh, (Beirut: dar al-Kutub al-Ilmiyah, 1982), hlm.217

${ }^{15}$ Az-Zamakhsyari, Tafsir al-Kasysyaf,' Jilid 2, (Beirut: Dar al-ma 'rifah, 1988), hlm. 582.

${ }^{16} \mathrm{Ibid}$, jilid. 3, hlm. 241. 
ditopang dengan ruh ini sepanjang hidupnya. Oleh sebab itu mendominasi sifat ruhani pada dirinya, tampil ayat-ayat Allah padanya pada masa ia masih kanak-kanak dan masa dewasa.

Bila diperhatikan ayat-ayat ini bahwa kata ruh terdapat di dalam alQuran menunjukkan bahwa ia adalah ciptaan yang diatur oleh Allah Swt. Inilah yang dikukuhkan oleh Ibnu Qayyim di berbagai tempat, di antaranya ia berkata: peniupan ruh kepada Adam as apakah itu merupakan perbuatannya sendiri atau apakah ia objek penderita? Bagaimanapun jua jawabannya ruh yang ditiupkan kepada Adam as tidaklah qadim inilah yang menjadi materi ruh Adam, maka tentunya sama halnya dengan ruh Isa as baharu dan tidak qadim. ${ }^{17}$

2. Kata ruh juga digunakan untuk menunjukkan kepada malaikat dan wahyu. Seperti firman Allah Swt:

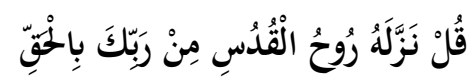

Artinya: "katakanlah: ia dibawa turun oleh ruh al-quds dari Tuhanmu dengan kebenaran",(QS. an-Nahal: 102).

Ruh al-quds ini adalah Jibril dan ia disandarkan kepada kata quds yang artinya suci. ${ }^{18}$ Begitu juga firman Allah Swt:

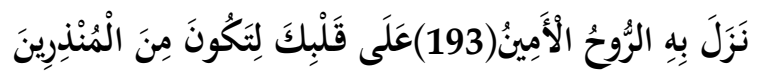

Artinya: "Ia dibawa turun oleh ruh yang terpercaya kepada hatimu agar engkau menjadi salah satu rasul yang memberi peringatan", (QS. asySyu 'ara: 193-194). Juga firman Allah Swt:

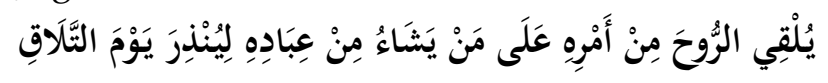

Artinya: "Dialah yang mengutus ruh dengan perintahNya kepada siapa yang

Dia kehendaki dari hamba-hambaNya untuk memberi peringatan mengenai hari pertemuan",(QS. Ghafir: 15).

Kata ruh juga digunakan dalam arti al-Quran, seperti firman Allah Swt:

$$
\text { وَكَذَلِكَ أَوْحَيْنَا إِلَيْكَ رُوحَا مِنْ أَمْرِنَا }
$$

Artinya: "Begitupula kami wahyukan kepadamu ruh melalui perintah Kami, (QS. as-Syura: 52. ruh dari perintah Kami maksudnya apa yang

\footnotetext{
${ }^{17}$ Ibnu al-Qayyim, ar-Ruh (Beirut: dar al-Kutub al-Ilmiyah, 1982), hlm. 210.

${ }^{18}$ Op Cit, jilid. 2, hlm. 428.
} 
diwahyukan kepada Nabi yaitu al-Quran, karena dengannya makhluk menjadi hidup agamanya sebagaimana jasad hidup dengan adanya ruh. ${ }^{19}$

Esensinya kata ruh muncul dalam al-Quran menunjukkan bahwa dia adalah ciptaan Allah Swt juga kadang digunakan bermakna malaikat, wahyu dan al-Quran. Namun hakikatnya ia adalah terkait dengan perintah Allah Swt. Inilah yang menjelaskan mengenai ketersembunyian dan misteri ruh tersebut sebagaimana yang diketahui secara umum.

3. Ruh bisa berarti kekuatan, keteguhan, pertolongan yang diberikan Allah kepada hamba-hamba yang beriman yang Dia kehendaki sebagaiman firman Allah Swt:

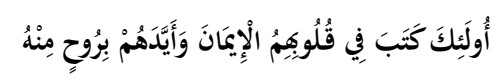

Artinya: "mereka itulah yang ditetapkan ke dalam hati mereka Iman dan Allah menolong mereka dengan ruh dariNya", (QS.al-Mujadilah: 22).

4. Ruh juga bisa berarti Jibril as, sebagaimana firman Allah Swt:

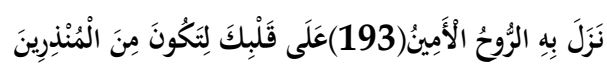

Artinya: "Ia dibawa turun oleh ruh yang terpercaya kepada hatimu agar engkau menjadi salah satu rasul yang memberi peringatan",(QS. asy-Syu ara: 193194). firman Allah Swt yang berbunyi :

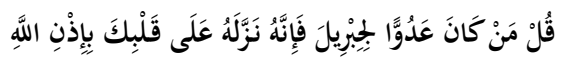

Artinya: "Katakanlah: barang siapa yang menjadi musuh bagi Jibril maka sesunggunya Dia ( Allah) menurunkan Jibril kepada hatimu dengan izinNya",(QS. al-Baqarah: 97). Juga firman Allah Swt:

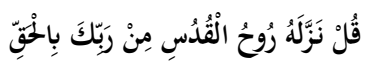

Artinya: "Katakanlah; ia dibawa turun oleh ruh al-Quds dari Tuhamu dengan kebenaran",(QS. an-Nahal: 102).

5. Ruh yang ditanya oleh kaum Yahudi, kebanyakan kaum salaf bahkan mereka semua berpendapat bahwa ruh yang ditanyakan di dalam surat al-Isra bukanlah arwah anak Adam namun dia adalah ruh yang diberitakan oleh Allah Swt di dalam kitabNya. Ia berdiri pada hari kiamat bersama para malaikat dan dia adalah malaikat yang sangat agung, maka dijawablah bahwa dia adalah merupakan perintah Allah Swt dan bahwasanya dia adalah ruh yang disebutkan di dalam al-Quran:

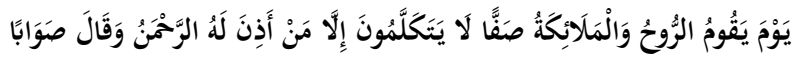

${ }^{19} \mathrm{Ibid}$, jilid. 3, hlm. 476. 
Artinya: "Pada hari ruh dan para malaikat berdiri dalam keadaan bersaf tidak berbicara kecuali siapa yang diberi izin oleh Allah Yang Maha Pengasih dan ia berkata dengan benar",(QS. an-Naba: 38). Begitu pula ia adalah ruh yang disebutkan dalam ayat berikut:

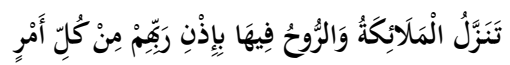

Artinya: "pada malam itu turun para malaikat dan ruh dengan izin Tuhan mereka dengan segala perintah", (QS. al-Qadar: 4).

f. Ruh juga bermakna al-Masih bin Maryam as, sebagaimana firman Allah Swt:

$$
\text { إنما المسيح عيسى ابن مريم رسول الله وكلمته ألقاها إلى مريم وروح منه }
$$

Artinya: "Sesungguhnya al-Masih bin Maryam adalah rasul Allah dan kalimatNya ia sampaikan kepada Maryam serta ruh dariNya".(QS. An-Nisa: 171).

Inilah beberapa penggunaan kata ruh di dalam al-Quran, dan adapaun arwah anak Adam as yang dengannya mereka hidup maka dalam hal ini Ibnu al-Qayyim berpendapat:" tidak terdapat penamaan arwah tersebut di dalam al-Quran kecuali dengan penamaan dengan kata nafsu" ${ }^{20}$. Ibnu al-Qayyim mengukuhkan pendapatnya dengan ayat-ayat Quran yang tertuju kepada jati diri manusia yaitu firman Allah Swt:

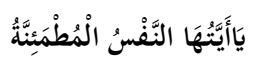

Artinya: "Wahai jiwa yang tenang", (QS. al-Fajar: 27). juga firman Allah Swt:

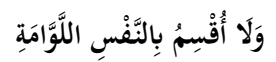

Artinya: "Sungguh aku bersumpah demi jiwa yang senantiasa mencela dirinya",(QS. al-Qiyamah: 2). Begitu juga firman Allah Swt:

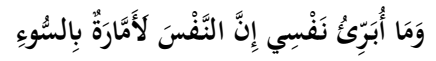

Artinya: "Aku tidak menganggap diriku suci karenan sesungguhnya nafsu senantiasa mengajak kepada keburukan",(QS. Yusuf: 53). Begitu juga firman Allah Swt:

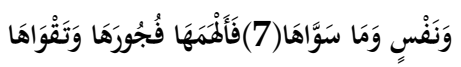

Artinya: "Demi jiwa dan apa yang menyempurnakannya, Allah mengilhamkan kepadanya jalan kefujuran dan ketaqwaaan",(QS. asy-Syams: 7). Juga firman Allah Swt:

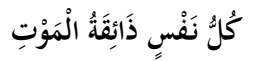

Artinya: "setiap diri merasakan mati", (QS.Ali Imran: 185). Adapun di dalam sunnah Nabi diri manusia dinyatakan dengan nafsu dan ruh.

Ada juga yang berpendapat bahwa ruh muncul tertera di dalam al-Quran disandarkan kepada Allah. Ibnu al-Qayyim menjelaskan penyandaran ini

${ }^{20} \mathrm{Ibnu}$ al-Qayyim, ar-Ruh (Beirut: dar al-Kutub al-Ilmiyah, 1982), hlm. 207. 
bahwa ruh adalah makhluk, hal ini dilakukannya agar sirna segala kesulitan dan anggapan yang muncul atas penyandaran ini, yaitu jika ia bersandar kepada Allah maka tentunya ia bersipat dengan kemahasucian Allah Swt. Ibnu al-Qayyim menjelaskan sandaran ini dengan pernyataan: adapun alasan mereka dengan menyandarkan ruh kepada Allah dengan firmanNya:

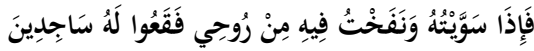

Artinya: "Dan ketika Kusempurnakan kejadiannya dan Aku tiupkan kepadanya dari ruhKu maka tersungkurlah kamu sujud",(QS. al-Hijir: 29).

Hendaklah diketahui bahwa penyandaran kepada Allah Swt ada dua jenis, pertama: sifat-sifat yang tidak berdiri dengan sendirinya seperti ilmu, qudrat, kalam, pendegaran dan penglihatan maka hal ini adalah penyandaran sifat kepada yang disifati maka ilmuNya, kehendakNya, kalamNya, kuasaNya, hayatNya adalah sifat-sifat bagiNya bukan termasuk ciptaan begitu pula wajahNya dan tanganNya. Kedua: penyandaran esensi yang terpisah darinya seperti rumah, unta, hamba, rasul, ruh maka hal ini adalah penyandaraan ciptaan kepada Penciptanya, buatan kepada Pembuatnya, namun penyandaran ini mengindikasikan pemuliaan, pengkhususan yang dengannya ciptaan yang disandarkan menjadi istimewa dari selainnya seperti rumah Allah Swt. Namun hal ini penyandaran kepada ketuhananNya yang menuntut penciptaan dan mengadakan. Sandaran yang umum menunjukkan penciptaan sedangkan yang khusus menunjukkan pilihan. Adapun penyandaran ruh kepadaNya tergolong penyandaran khusus bukan umum dan bukan bula penyandaran sifat kepada yang disifati. ${ }^{21}$

Pendidikan rohani ini banyak dijelaskan di dalam al-Quran di antaranya ialah :

1. Zikrullah (mengingat dan menyebut nama Allah )

Dalam hal ini Allah Swt berfirman dalam surat Al-Ahzab ayat 41:

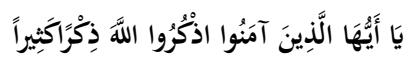

Artinya: "Hai orang-orang yang beriman, berzdikirlah (dengan menyebut nama) Allah, zikir yang sebanyak-banyaknya".

Ibnu Katsir menjelaskan mengenai ayat ini, Allah Swt berfirman seraya memerintahkan kepada hamba-hambaNya untuk memperbanyak mengingat dan menyebut Allah karena Dia telah memberikan berbagai macam nikmat dan Allah juga sudah menyiapka ganjaran yang besar bagi hamba banyak

\footnotetext{
${ }^{21} \mathrm{Ibid}, \mathrm{hlm} .207-208$.
} 
mengingatNya. ${ }^{22}$. Jelas dari ayat ini ada perintah untuk banyak-banyak mengingat dan menyebut asma Allah Swt. Zikir dari segi bahasa zahirnya adalah menyebut dan batinnya mengingat Allah Swt jadi ia memiliki dua aspek disebut dengan lidah dan diingat dalam hati. Inilah makna zikir secara khusus. Adapun maknanya secara umum adalah segala prilaku, perkataan ataupun keyakinan yang bertujuan menjalankan perintah Allah Swt dan menjauhi larangannya adalah zikir. Orang yang belajar agama untuk Allah adalah berzikir. Orang yang bekerja mencukupi keluarganya karena Allah adalah berzikir. Orang yang membantu orang lain karena Allah adalah berzikir. Orang yang merenungkan tanda-tanda kebesaran Allah Swt baik pada seluruh alam yang dia saksikan maupun dalam dirinya sendiri adalah berzikir. Orang yang bertawakkal yakin akan janji-janji Allah adalah berzikir. Begitu jua orang yang berjihad di jalan Allah adalah berzikir. Oleh sebab itu amal yang paling baik melebihi segala amal adalah zikrullah karena ia meliputi segala amal kebajikan yang ditujukan untuk Allah Swt sebagaimana sabda Rasulullah Saw:

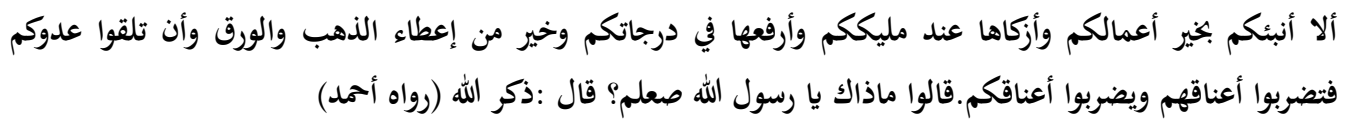

Artinya: Rasulullah Saw bersabda: Maukah kamu kuberitahu mengenai amal yang paling baik dan paling suci di sisi Tuhanmu dan paling tinggi derajatnya serta lebih dari bersedekah dengan emas dan perak atau berjihad di jalan Allah sehingga kamu memenggal leher musuhmu atau mereka memenggal lehermu. Para sahabat bertanya kepada Rasulullah Saw: amal apakah itu wahai Rasulullah Saw? Belia bersabda: menyebut dan mengingat Allah (diriwayatkan oleh Muslim). ${ }^{23}$

Jadi jelas zikir di sini adalah ibadah yang paling tinggi derajatnya di mata Allah Swt. Karena zikir adalah manifestasi penghambaan yang total kepada Allah Swt mencakup segala aspek kebaikan. Sehingga jika tidak terlantunkan lagi zikir kepada Allah, maka dunia ini akan kehilangan fungsi hingga Allah Swt melipat seluruh langit dan buminya mengakhiri kehidupan dunia ini sebagaimana sabdanya:

لا تقوم الساعة حتى لا يقال في الأرض : الله, الله

${ }^{22}$ Ibnu Katsir, Tafsir al-Quran, Jilid. II (Giza: Muassasah Qurthubah, 2000), hlm.181

${ }^{23}$ Ahmad Bin Hanbal, Musnad juz.5, (Cairo: Dar al-Kutub al-Ilmiah, 1995), hlm.195 
FITRAH Jurnal Kajian Ilmu-ilmu Keislaman

Vol. 02 No. 2 Desember 2016

Artinya: tidak akan datang kiamat hingga tidak lagi diucapkan di bumi ini Allah, Allah, Allah. (diriwayatkan oleh Tarmizi). ${ }^{24}$

Bahkan jika seorang ingin mengetahui kedudukannya di sisi Allah Swt maka hendaklah ia melihat seberapa penting dan seringkah Allah terbersir dalam hatinya. Jika ia menjadikan Allah pada urutan yang keseratus dalam hatinya maka jelaslah kedudukannya di mata Allah paling terbelakang. Allah Swt akan mengabaikannya sebagaimana ia mengabaikan Allah Swt. Sebaliknya jika seorang menempatkan Allah paling utama dan paling sering diingat oleh hatinya maka dialah orang yang paling utama dan paling sering mendapat pertolongan Allah Swt.

Hakikat zikir adalah melupakan segala sesuatu selain Allah sebagaimana yang dinyatakan Zunnun Al-Mishri seorang arif billah. ${ }^{25}$ Karena Allah Swt jauh lebih berharga dari seluruh alam yang dijadikanNya, dan semua alam ini adalah batil. Hal ini sebagaimana sabda Rasulullah Saw:

$$
\text { اصدق الكلام ما قاله العرب الاكل ما سوى الله باطل }
$$

Artinya : sebenar-benar perkataan yang dikatakan orang arab adalah segala sesuatu selain Allah adalah bathil.

Maksud bathil di sini adalah tiada. Karena pada hakikatnya seluruh alam ini berawal dari ketiadaan. Artinya bagaimana seorang lebih mengejar dan mengutamakan yang bathil daripada yang haq. Oleh sebab itu seorang arif berkata: barang siapa mengejar dan menemukan Allah maka dia akan memperoleh segalanya dan barang siapa yang tidak mencari dan menemukan Allah dia tidak akan memperoleh apa-apa. Dengan kata lain seluruh kehidupannya menjadi sia-sia belaka seperti fatamorgana yang diduga ada tapi kenyataannya tidak ada, karena pada akhirnya disebabkan kelalaian dan kelupaannya kepada Allah menghantarkannya kepada neraka.

Atas dasar ini Rasulullah Saw senantiasa mengingat Allah Swt dalam segala keadaannya sebagaimana diriwayatkan dalam sebuah hadis:

$$
\text { كان رسول الله صلعم يذكر الله في كل احيانه }
$$

Artinya: Rasulullah Saw senantiasa mengingat Allah Swt dalam segala keadaannya. Bahkan pada saat tidurpun Rasulullah Saw berzikir mengingat Allah sebagaimana sabdanya:

$$
\text { تتام عيني ولا ينام قلبي }
$$

${ }^{24}$ Diriwayatkan oleh Tarmizi dengan nomor hadis 2208 dalam bab al-Fitan nomor 35

${ }^{25}$ Al-Qusyairi, ar-Risalah al-Qusyairiyah, (Beirut: Darul Khair, 1995), hlm. 222 
Artinya: mataku tertidur namun hatiku tidak.

Hati Rasul Saw senantiasa hidup mengingat Allah Swt, berkekalan dalam mengingatNya. Inilah salah satu hal yang paling penting diteladani. Karena zikir ini begitu banyak manfaatnya mencakup segala kebaikan dunia dan akhirat. Di antara manfaatnya majlis zikir adalah taman suraga sebagaimana yang disebutkan dalam hadits yang masyhur diriwayatkan dari Rasulullah Saw:

إذا رأيتم رياض الجنة فارتعوا فيها, فقيل له وما رياض الجنة ؟ مجالس الذكر Artinya: Jika kamu melihat taman-taman surga maka singgahlah kamu padanya, kemudian ditanyakan kepada beliau, apa itu taman-taman surga ? beliau menjawab: majlis-majlis zikir.(diriwayatkan oleh Tarmizi). ${ }^{26}$ Maksudnya zikir ini mengantarkan pelakunya kepada surga.

Kedua, zikir adalah jalan menuju kewalian sebagaimana yang dinyatakan Syaikh Abu Ali ad-Daqqaq. Ketiga, orang yang berzikir menjadi teman duduk Allah Swt dimana ia tidak akan sengsara selamanya begitu jua orang yang hadir pada majlis tersebut sebagaimana diriwayatkan dalam sebuah hadis. Bahkan Imam al-Qusyairi menyatakan dalam bukunya jika zikir itu sudah duduk dalam hati maka setiap setan yang mendekat kepada orang yang berzikir tersebut akan kesurupan setan tadi. Selanjutnya zikir membantu merinngankan seorang pada saat sakratul maut sebagaimana yang diriwayatkan dari Rasulullah Saw bahwasanya setiap jiwa yang berpisah dengan raganya akan merasakan haus kecuali orang yang banyak mengingat Allah Swt. Zikir juga dapat memberatkan timbangan amal kebajikan seorang di akhirat, sebagaimana sebuah riwayat menyebutkan bahwa dua kata yang mudah diucapkan oleh lidah dan berat timbangannya di mizan hari kiamat yaitu subhanallah walhamdu lillah.

Allah Swt juga berfirman dalam surat al-Baqarah ayat 152:

فاذكروني أذكركم

Artinya: "Ingatlah Aku maka Aku akan mengingat kamu. Jelas dari ayat ini zikir adalah sarana atau jalan untuk menguatkan hubungan dengan Allah Swt dimana dengan mengingatNya maka si hamba akan diingat oleh Allah serta dipelihara dan ditunjuki. Bahkan zikir adalah jalan untuk mencapai kewalian atau derajat kedekatan dengan Allah Swt.

2. Shalat

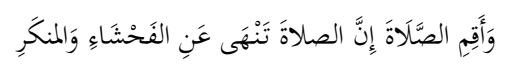

${ }^{26}$ Nomor hadis 3504 dalam bab Asmaul Husna. 
Artinya; "dan dirikanlah shalat sesungguhnya shalat mencegah dari perbuatan keji dan mungkar."(QS.al-Ankabut :45).Wahbah az-Zuhaili menjelaskan ayat ini bahwa Allah Swt memerintahkan untuk mendirikan shalat pada waktu-waktunya yang telah tertentu dan senantiaslah kamu melakukan hal tersebut karena sesungguhnya shalat dapat mencegah orang-orang yang beriman dari melakukan segala amal yang buruk yang tidak diakui syari at. ${ }^{27}$

Namun kenapa justru perbuatan keji dan munkar masih saja dilakukan oleh sebagain orang yang shalat. Ini berarti ada yang salah ketika ia memaknai shalat tersebut. Di dalam al-Quran sering diperintahkan dirikanlah shalat bukan kerjakanlah shalat. Apa beda antara mendirikan dan mengerjakan? Umpamakan ketika mendirikan bangunan yang kokoh maka artinya bangunan itu terus berdiri tegak selama tidak dirobohkan atau lapuk dimakan zaman. Jadi, mendirikan shalat artinya bukan hanya sekedar mengerjakan shalat yang lima waktu tapi ditambah dengan menjiwai makna shalat tersebut sepanjang waktu. Sebelum shalat difardhukan lima waktu, terlebih dalu difardhukan sebanyak 50 waktu; artinya setiap setengah jam atau lebih harus melakukan shalat. Itu artinya harus terus shalat. Inilah yang dimaksud dengan firman Allah dalam surat alMu'minun ayat 9:

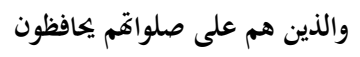

Artinya: Dan mereka yang memelihara shalat-shalat mereka.

Di dalam ayat yang lain disebutkan dan orang-orang yang da'im atau senantiasa berkekalan shalatnya. Jikalau berkekalan dalam shalat artinya berkekalan dalam mengingat Allah, maka tentunya akan terpelihara dari segala kemaksiatan. Karena bagaimana bisa seorang yang senantiasa merasakan kehadiranNya dapat berbuat maksiat. Bila seseorang senantiasa merasa berhubungan dengan Allah, merasa diawasi olehNya, maka secara otomatis ia akan terpelihara dari segala keburukan dan kemaksiatan. Inilah shalat yang dapat mencegah dari perbuatan keji dan mungkar. Yang dituntut dari muslim adalah mendirikan shalat dan bukan sekedar mengerjakan shalat. Artinya di samping shalat lima waktu yang telah dilakukan juga harus senantiasa merasakan kehadiran Allah sepanjang waktu sama sepertui saat melakukan shalat lima waktu tersebut. Oleh sebab itu kaum arif billah berkata, lupa mengingat Allah sesaat adalah kufur nikmat. Di dalam hadis juga disebutkan tidak ada yang lebih disesali seorang arif billah melainkan sesaat ia pernah

${ }^{27}$ Wahbah az-Zuhaili, at-tafsir al-Wazij, (Beirut: Dar al-Fikr, tt), hlm. 402 
melupakan Allah. Jadi jelas shalat merupakan pendidikan rohani yang menghubungkan hamba kepada Tuhan dan dapat mewujudakn akhlak mulia karena mencegah dari perbuatan keji dan mungkar.

Shalat yang berkekalan inilah yang diterima Allah sebagaiman firman Allah di dalam hadis qudsi yang diriwayatkan Rasulullah Saw dari Rabbun Jalil:

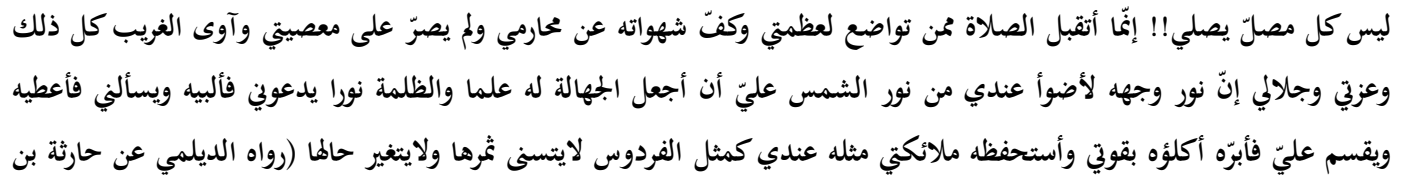

Artinya: "Bukanlah setiap orang yang shalat itu shalat karena sesungguhnya Aku menerima shalat dari orang yang merendahkan diri untuk kemahaagunganKu dan menahan syahwatnya dari hal yang diharamkan dan tidak berketerusan berbuat maksiat serta menolong orang yang asing semua itu jika dilakukannya maka demi kemahamulianKu dan keagunganKu sesungguhnya cahaya wajahnya lebih terang di sisiKu dari cahaya matahari, Saya juga merasa berkewajiban untuk mengubah kebodohannya menjadi ilmu dan kegelapannya menjadi cahaya, ia berdoa kepada Saya makaSsaya akan mengabulkannya, ia meminta kepadaKu maka Aku akan memberinya, Ia bersumpah atasKu maka Aku akan mengabulkannya, Aku memeliharaNya dengan kekuatanKu menyuruh para malaikatKu untuk menjaganya. Perumpamaannya bagiKu seperti surga Fidaus yang tidak busuk buah-buahannya dan tidak berubah perihalnya. (diriwayatkan oleh ad-Dailami dari Harisah bin Wahab RA).

Jadi jelas di dalam hadis ini tanda diterima shalat adanya perubahan karakter seorang yang rendah hati dan patuh terhadap perintah Allah meninggalkan hal yang diharamkan dan berhenti berbuat kemaksiatan serta mengejewantahnya sikap kesalehan sosial dengan memberi pertolongan kepada sesama walaupun itu orang asing sekalipun. Oleh sebab itu perintah mendirikan shalat sering diiringi dengan printah menunaikan zakat. Artinya tanda benarnya hubungan seorang dengan Tuhannya adalah baiknya perilakunya terhadap sesama makhluk lainnya. Tanda buruknya hubungan seorang dengan Tuhannya adalah buruknya perilakunya terhadap makhluk lainnya dengan mezhalimi mereka, memeras mereka, menipu mereka dan lain sebagainya. Karena ditegaskan di dalam sebuah hikmah : barang siapa membaguskan hubungannya dengan Allah maka Allah akan membaguskan hubungannya dengan sesama manusia. Jadi Islam mementingkan hubungan vertikal dan horizontal. Bagusnya hubungan vertikal terindikasi dengan bagusnya hubungan horizontal atau sosial. 
FITRAH Jurnal Kajian Ilmu-ilmu Keislaman

Vol. 02 No. 2 Desember 2016

Karena misi agama pada dasarnya adalah membentuk akhlak yang mulia baik itu akhlak kepada Allah atau akhlak kepada seluruh makhluk Allah.

3. Puasa

Puasa juga merupakan latihan rohani dan jasmani untuk mewujudkan taqwa dan mendekatkan diri kepada Allah. Karena puncak kenikmatan puasa adalah bertemu dengan Allah Swt. Allah Swt berfirman dalam surat al-Baqarah ayat 183:

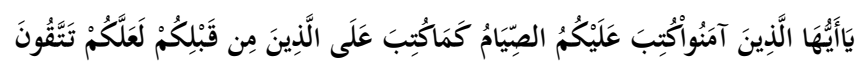

Artinya: "Wahai orang yang beriman diwajibkan kepada kamu puasa sebagaimana diwajibkan atas orang-orang sebelum kamu agar kamu bertaqwa".

Puasa ini merupakan penguatan spritual manusia dan penguatan hubungan kepada Allah sehingga menghasilkan ketaqwaan. Al-Maragi dalam tafsirnya menjelaskan bahwa Allah Swt mewajibkan puasa seperti diwajibkan atas umat-umat sebelumnya, karena puasa ialah sarana yang paling besar dalam membersikan jiwa dan membenahinya. Ia adalah ibadah yang paling kuat untuk mengekang syahwat nafsu. Oleh sebab itu puasa ini dikenal dalam seluruh agama bahkan telah dilakukan oleh orang Mesir kuno. Kemudian puasa ini dilakukan oleh orang Yunani dan Romawi begitu juga orang India. Di dalam Taurat dan Injil tidak dijelaskan kewajibannya namun puasa ini dipuji sebagai ibadah pendekatan kepada Allah Swt. Dengan puasa ini manusia terlatih untuk mengekang nafsu syahwatnya di samping itu pula menanamkan kepada dirinya merasa diawasi oleh Allah Swt setiap detiknya. Karena hanya dia dan Tuhannya yang tahu bahwa ia sedang berpuasa. Dengan demikian, jelas puasa dapat mewujudkan ketaqwaan dan hubungan yang dekat dengan Allah Swt. ${ }^{28}$

Nabi Saw bersabda :

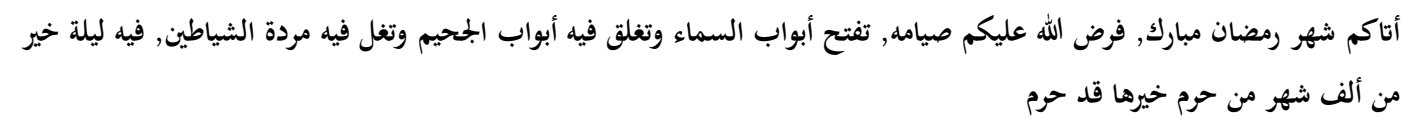

Artinya: "Telah datang kepadamu bulan yang penuh berkat, Allah mewajibkan bagi kamu berpuasa padanya, dibukakan padanya pintu-pintu rahmat, ditutup pintu-pintu neraka dan dibelenggu setan-setan, padanya ada satu malam yang lebih baik dari seribu bulan dan barang siapa yang tidak mendapat kebaikan dari bulan itu maka sungguh-sungguhlah ia orang yang amat merugi. Pembukaan pintu rahmat karena banyaknya berkah yang diperoleh pada bulan ini yang tidak terhingga, bahkan dalam satu riwayat Rasulullah Saw pernah bersabda; kalaulah ummatku tahu mengenai keutamaan yang ada 1946), hlm.70

${ }^{28} \mathrm{Ahmad}$ Mushtafa Al-Maraghi, Tafsir al-Maraghi Jilid. 2, (Cairo : Maktabah Ali al-Halabi, 
pada ramadahan maka mereka akan berangan-angan sepanjang tahun adalah bulan Ramadhan.

Pintu neraka ditutup pertanda akan hilangnya murka Allah dan bertajallinya ia dengan ridha dan cinta. Pembelengguan setan ibarat dari hilangnya kuasa setan untuk menggoda manusia. Hal ini disebabkan di dalam satu riwayat dari Ibnu Abbas ra bahwasanya ia berkata: jika bergerak seorang didasari oleh nafsunya maka menyebarlah hawa buruk hingga mengundang setan untuk menggodanya dan menjerumuskannya dan jika bergerak seorang didasari ruhaninya menyebarlah hawa baik yang mengundang malaikat untuk mendukungnya melakukan kebajikan. Dari riwayat tersebut dapat dipahami di dalam bulan ramadhan seseorang muslim berupaya mengekang nafsu sehingga tidak menyebar hawa buruk yang dapat mengundang setan. Mungkin inilah yang dimaksud dalam hadits Nabi tersebut bahwa pada bulan Ramadhan setansetan terbelunggu karena dia tidak menemukan jalan masuk untuk menggoda anak Adam.

Rahmat yang selanjutnya sebagaimana yang disebutkan di dalam hadist Qudsi diriwayatkan oleh Imam Bukhari dan Muslim:

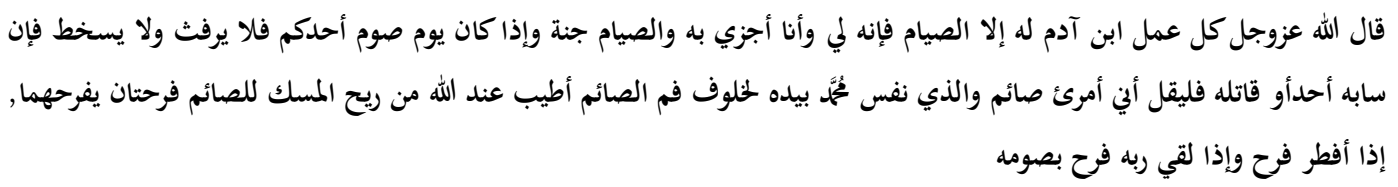

Allah Azza Wa Jalla berfirman: "semua amal anak Adam adalah untuknya kecuali puasa karena sesungguhnya puasa itu untukKu dan Aku lah yang langsung memberi ganjarannya, puasa adalah perisai jika pada hari puasa maka janganlah kamu berbuat rafats ( segala hal yang menjurus kepada hubungan sex) jangan pula marah dan jika salah seorang mencelanya atau melawannya hendaklah ia berkata sesungguhnya saya berpuasa dan demi jiwa Muhammad yang ada di dalm genggamanNya aroma bau mulut orang yang berpuasa di sisi Allah lebih wangi dari aroma kesturi, orang yang berpuasa memiliki dua kebahagian pertama ketika ia berbuka dan kedua ketika ia bertemudengan Tuhannya dan iapun merasa senang dengan puasanya."

Di dalam hadits sebelumnya terlihat begitu banyak rahmat Allah yang diberikan kepada orang yang berpuasa. Allah langsung memberi ganjaran kepada yang berpuasa, Allah menyukai dan menyintai orang yang berpuasa hingga aroma mulutnyapun sangat wangi bagi Allah, dan ia mendapat kesempatan berjumpa dengan Allah kelak. Inilah ia yang menjadi puncak kenikmatan. Bahkan di surga sendiri nikmat yang tertinggi adalah pertemuan dengan Allah Swt. Orang yang berpuasalah yang memperoleh kenikmatan tersebut. Di dalam hadist Qudsi Allah berfirman: 


$$
\text { من أحب لقائى أحبت لقاءه }
$$

Artinya: "Barang siapa yang senang dan cinta untuk bertemu denganKu maka Akupun akan senang dan cinta bertemu dengannya".

4. Tazkiyah

Diantara tujuan utama diutusnya Nabi Muhammad saw, adalah untuk memberi bimbingan kepada umat manusia dalam rangka tazkiyatunnafs (membentuk jiwa yang suci), sebagaimanafirman-Nya :

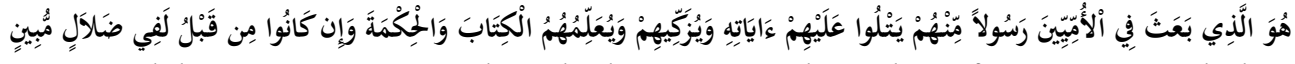

Artinya: "Dialah yang mengutus kepada kaum yang buta huruf seorang rasul dari golongan mereka, yang membacakan ayat-ayat-Nya kepada mereka, mensucikan jiwa mereka dan mengajarkan kepada mereka kitab dan hikmah. Dan sesungguhnya mereka sebelumnya dalam kesesatan yang nyata." (QS. Al Jum'ah : 2).

Tazkiyah secara bahasa adalah masdar dari kata ( مَّكَّ ( ) yang berarti ) yaitu, mensucikan. ${ }^{29}$ At-Thabari menjelaskan mengenai makna tazkiyah dalam ayat ini adalah mensucikan mereka dari kotoran kufur dan sifat tercela serta dengan amal saleh. ${ }^{30}$ Karenanya wajib bagi setiap orang yang mengharapkan pahala dari Allah dan kebahagiaan abadi di hari kemudian untuk memberikan perhatian secara khusus agar ia mampu mensucikan diri. Keberuntungan dan kesuksesan seseorang itu dapat diraih tergantung bagaimana ia mau mensucikan dirinya (tazkiyatun nafs), sebagaimana firman-Nya :

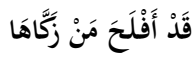

Artinya: "Sesungguhnya telah beruntunglah orang yang mau mensucikan jiwanya." (Qs. As Syams : 9)

Jadi dengan tazkiyah ini seorang dapat mensucikan dirinya atau dalam istilah tasawuf takhalli dan tahalli sehingga tersingkap tabir yang dikenal dengan tajalli. Tersingkap tabir ini yang mengindikasikan kedekatan hubungan dengan Allah Swt.

5. Muraqabah

Allah SubhannahuwaTa'alaberfirman:

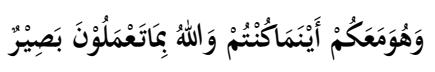

\footnotetext{
Wasith, I/396

${ }^{30}$ At-Thabari, Tafsir at-Thabari Jilid. 22, (Cairo : Dar Hajar,2001), hlm. 625
}

${ }^{29}$ Lois M luf, Al MunjidfilLughoh, (Cairo: Maktabah Katolik, tt), hlm. 303, Al Mu'jam Al 
Artinya: "Dan Diabersamamu di manasaja kamu berada. Dan Allah melihat apa-apa yang kamu kerjakan". (Al-Hadid: 4).

Makna ayat ini, bahwa Allah mengawasi dan menyaksikan perbuatanmu kapan saja dan di mana saja kamu berada. Di darat ataupun di laut, pada waktu malam maupun siang. Di rumah kediamanmu maupun di ruang terbuka. Segala sesuatu berada dalam ilmuNya, Dia dengarkan perkataanmu, melihat tempat tinggalmu, di mana saja adanya dan Dia mengetahui segala yang kamu sembunyikan serta yang kamu fikirkan". ${ }^{31}$ Tidak terwujud ketaqwaan jika peserta didik tidak terlatih untuk senantiasa bermuraqabah merasakan kehadiran dan kebersamaan Allah dengannya dalam setiap waktu. Ketika peserta didik merasakan hal ini maka dia akan takut melakukan segala bentuk perbuatan maksiat dimana saja ia berada karena ia yakin bahwa Allah Swt senantiasa besertanya. Selanjutnya ia juga akan sanggup dalam menghadapi berbagai rintangan dan tantangan karena ia yakin bahwa Allah Maha Kuasa bersamanya menyelesaikan segala masalah yang ia hadapi.

Pendidikan pada masa ini kering dari pendidikan muraqabah semisal ini. Karena itu banyak orang yang mengaku muslim melakukan shalat, puasa, zakat bahkan haji namun masih bergelimang dalam segala bentuk kemaksiatan. Sudah berhaji namun masih rajin korupsi. Sering shalat ke Masjid namun masih sering menipu. Seakan-akan ibadahnya tersebut tidak bermanfaat baginya karena tidak dapat mencegahnya dari segala bentuk kemaksiatan. Artinya pada saat shalatpun ia tidak merasakan kehadiran Allah Swt karena shalat adalah sebuah pembiasaan bagi setiap muslim agar senantiasa hadir bersama Allah dan senantiasa merasa diawasi Allah Swt.

Dalam lembaran sejarah kita dapat memetik sebuah kisah keteladanan dalam hal muraqabah ini. Kisah ini mengenai syekh Sahal at-Tustari dan pamannya seorang zahid yang bernama Muhammad bin Siwar. Sahal pada saat usianya masih 3 tahun terbangun pada malam hari kemudian melihat pamannya sedang melakukan shalat malam sampai terbitnya fajar. Sahal merasa kagum dengan perihal pamannya ini, sehingga dia sering bangun malam untuk melihat pamannya shalat. Pada suatu malam pamannya tersadar bahwa ia sering diamati oleh kemanakannya lantas ia berkata kepada Sahal: wahai Sahal pergilah tidur engkau telah membuat hatiku gundah. Namun dia enggan tidur ingin melihat pamannya melakukan shalat malam. Karena ia bersikeras pamannyapun

${ }^{31}$ Ibnu Katsir, jilid. 4, hlm. 304 
berpaling menghadap kepadanya : wahai Sahal mengapa engkau tidak berzikir mengingat Allah Swt yang telah menciptakanmu? Ia menjawab: bagaimana saya berzikir mengingatNya? Pamannya berkata kepadanya: katakanlah dengan hatimu ketika kamu mengenakan pakainmu sebanyak 3 kali tanpa engkau menzhaharkannya dengan lidahmu: Allah bersamaku, Allah menyaksikanku, Allah melihatku. Lantas ia melakukan hal tersebut selama tiga hari, kemudian pamannya menganjurkan kepadanya untuk menambah jumlah bilangannya menjadi tujuh kali kemudian selanjutnya 11 kali. Hasilnya sebagaimana yang diceritakan oleh Sahal sendiri: saya menemukan rasa nikmat di dalam hati saya. Kemudian pamannya menganjurkannya untuk senantiasa melakukan zikir ini seraya ia berkata kepadanya: peliharalah yang saya ajarkan dan senantiasalah engkau melakukannya sampai kamu masuk ke dalam kuburmu karena sesungguhnya ia akan bermanfaat bagimu di dunia dan di akhirat. Kemudian pada satu kesempatan pamannya berkata lagi kepadanya: barang siapa yang merasa bersama Allah, dilihat dan disaksikan Allah apakah pantas ia berbuat maksiat di hadapan Allah ? pernyataan ini amat membekas bagi dirinya dan menempanya menjadi ulama akhirat yang luar biasa yang memiliki prestasi spritual yang hebat. ${ }^{32}$

Prestasi itu di antaranya pada usia 7 tahun beliau sudah menghafal quran. Ia berpuasa bertahun-tahun makannya hanya sepotong roti. Ia meninggalkan segala bentuk kemaksiatan dengan menyibukkan waktunya shalat, zikir, puasa dan menuntut ilmu. Ahmad bin Salim menceritakan mengenainya: Sahal at-Tustar berzikir sejak usianya 3 tahun, berpuasa sejak usianya 5 tahun, meninggalkan segala keinginan syahwat pada usia 7 tahun, merantau menuntut ilmu sejak usianya 9 tahun. Pada masa ini dia sudah mampu bertanya kepada para ulama dengan berbagai pertanyaan yang sangat sulit sehingga tidak ditemukan jawabannya kecuali dia yang mengetahuinya dan ini terjadi pada saat usianya 11 tahun, kemudian muncullah berbagi karamah di dalam dirinya. Al-'Arif al-Minawi menjelaskan di dalam kitab thabaqatnya bahwa Sahal at-Tustari menjadi orang yang paling alim di Tustar pada saat usianya masih 12 tahun. ${ }^{33}$

6. Ridha dengan ketentuan Allah ${ }^{34}$

\footnotetext{
${ }^{32}$ Jaudah Muhammad Abul Yazid al-C, Bihar al-Wilayah al-Muhammadiyah Fi Manaqib A'lam as-Shufiyah, (Cairo: Dar al-gharib, 1998), hml. 317

${ }^{33} \mathrm{Ibid}, \mathrm{hlm} .318$

${ }^{34}$ Abu Thalib al-Makki, Qutul Qulub, (Cairo: Dar al-Kutub al-Ilmiah, tt), hlm. 230-239
} 
Ridha kepada Allah Swt merupakan maqam perjalanan spiritual yang tertinggi dari keyakinan kepada Allah Swt. Allah Swt berfirman:

هُلْ جَزَاءُ الاحسَانِ إلاّ الاحسَانُ Artinya: "Balasan kebaikan adalah tiada lain kebaikan itu sendiri.(QS.ar-Rahman :60)

Barang siapa yang benar-benar bersikap ridha terhadap Tuhannya, Tuhannya juga akan ridha dan suka kepadanya. Allah Swt membalas keridhaan dengan keridhaan yang sama. Inilah puncak dari anugerah dan pemberian Allah Swt. Sebagaimana firman Allah Swt

$$
\text { رَضِيَ اللّه عَنْهُمْ وَرَضُوا عَنُُْ }
$$

Artinya: "Allah senang kepada mereka dan mereka juga senang terhadap Allah Swt.(QS. At-taubah: 100),

Allah Swt telah mengangkat balasan dari ridha dalam darajat yang paling tinggi yaitu di surga Adnan surga yang tertinggi. Diriwayatkan bahwasanya Rasulullah Saw pernah bersabda kepada sekelompok orang-orang yang beriman: Siapakah kamu ? mereka menjawab: kami adalah orang-orang yang beriman. Rasulullah Saw kembali bertanya: apa tanda keimanan kamu ? mereka menjawab: Kami bersabar ketika mengalami ujian, bersyukur ketika memperoleh nikmat dan ridha ketika terjadinya qadha dan qadar. Rasulullah Saw kembali bersabda: kalian benar-benar beriman demi Tuhan yang menguasai Ka 'bah. Jelas tanda keimanan adalah ridha terhadap ketentuan Allah Swt.

Begitu jua Luqman al-Hakim menjadikan ridha sebagai syarat keimanan dimana iman tidaklah benar kecuali dengannya. Beliau berkata dalam sebuah wasiatnya : iman itu mempunyai 4 rukun dan tidaklah benar sebuah iman tanpa keempatnya. Sebagaimana halnya jasad tidak menjadi benar kecuali dengan kedua tangan dan kedua kaki. Kemudian ia menyebutkan di antara rukun yang empat itu adalah ridha terhadap qadha dan qadar.

Di antara tanda keridhaan menurut orang-orang yang ridha kepada Allah ialah: tidaklah boleh seorang hamba berkata: hari ini sangat panas atau hari ini sangat dingin. Jangan pula ia berkata: kefakiran adalah bala dan ujian, keluarga adalah beban dan kepenatan. Pekerjaan adalah kesusahpayahan dan kesulitan. Hatinya tidak kehilangan keseimbangannya yang dapat membuatnya tertipu. Bahkan hatinya rela dan berserah diri akalnya pun menjadi tenang. Ia berserah diri dengan adanya manisnya pengaturan Allah dan bagusnya hukum takdir. Sebagaimana Umar bin Abdul Aziz pernah berkata: setiap paginya tidak ada yang lebih kusenangi dari pada menanti ketentuan taqdir Allah Swt. 
Di dalam sebuah hadis yang dijelaskan bahwa barang siapa yang ridha dengan sedikitnya rezeki yang datang dari Allah maka Allah akan meridhai amalnya yang sedikit. Dalam hadis lain ditegaskan: barang siapa yang ingin mengetahui kedudukannya di sisi Allah maka hendaklah ia memperhatikan bagaimana kedudukan Allah pada dirinya, karena Allah Swt menempatkan kedudukan seorang di sisinya sesuai dengan bagaimana ia memposisikan Allah di dalam dirinya.

Diriwayatkan pula dalam hadis dengan sanad yang hasan seperti musnad dari Hamad bin Salamah dari Tsabit al-bannani dari Anas bin Malik: apabila datang hari kiamat maka Allah Swt akan menumbuhkan bagi sekelompok umatku sayap-sayap maka merekapun terbang dari kuburan mereka ke surga-surga. Mereka bergembira dan bersenang-senang padanya sesuka mereka. Kemudian beliau bersabda: malaikat bertanya kepada mereka: apakah kamu sekalian mengalami hisab ? mereka menjawab :kami tidak melihat ada hisab. Malaikat kembali bertanya: apakah kamu melihat titian sirath? Mereka menjawab: kami tidak melihat titian sirath. Maka kembali malaikat bertanya: apakah kamu melihat neraka Jahannam ? mereka menjawab: mereka menjawab: kami tidak melihat apapun jua. Malaikat bertanya: dari umat manakah kamu ? mereka menjawab: kami adalah umat Muhammad Saw. Para malaikat berkata: demi Allah, beritakan kepada kami apakah amalan kamu dahulunya di dunia ? mereka berkata ada dua sifat yang kami miliki sehingga Allah Swt memberikan kepada kami kedudukan ini, dengan keutaman rahmat Allah Swt. Para malaikat bertanya: apakah yang kedua sifat itu ? mereka menjawab: jikalau kami dalam keadaan sendiri kami malu berbuat maksiat kepada Allah dan kami ridha terhadap rezeki yang sedikit yang diberikan Allah Swt. Para malaikat berkata: kamu semua berhak mendapat kedudukan ini.

Tuhanmu suatu perkara yang dengannya Ia dapat ridha terhadap kami. Lantas Musa as berkata: wahai Tuhanku sesungguhnya Engkau mendengar apa yang mereka katakan, Allah Swt kemudian berfirman: wahai Musa katakan kepada mereka hendaklah mereka ridha terhadapKu maka Aku akan meridhai mereka.

Ja 'far bin Sulaim as-Sahn'I berkata bahwasanya Sufyan as-Tsauri berkata di hadapan Rabi 'ah : Wahai Allah ridhailah kami. Rabi ’ah berkata: apakah kamu tidak malu meminta kepada Allah untuk meridhaimu sementara engkau tidak ridha kepadaNya? Ia menjawab: Aku minta ampun kepada Allah. Dijelaskan 
dalam sebuah riwayat hadis bahwa orang yang paling banyak rasa gundahnya dan keluhannya di dunia adalah orang yang paling banyak rasa susahnya di akhirat. Orang yang paling sedikit rasa gundah dan keluhannya di dunia adalah orang yang paling sedikit susahnya di akhirat.

Dalam sebuah riwayat dijelaskan bawah Musa as bertanya kepada Tuhannya: ya Allah tunjukilah aku kepada sesuatu perkara yang dapat mendatangkan ridhaMu sehingga aku dapat mengamalkannya? Maka Allah Swt mewahyukan kepadanya: bahwa keridhaanKu ada dalam hal yang kamu benci sementara kamu tidak sabar menghadapi apa yang kamu benci. Ia kembali bertanya: Wahai Tuhanku tunjukilah aku kepada hal tersebut. Allah berfirman : sesungguhnya keridhaanKu ada pada keridhaanmu terhadap ketentuanKu.

Dalam sebuah munajatnya Musa as pernah bertanya kepada Tuhannya: wahai Tuhanku makhluk mana yang paling Engkau cintai ? Allah berfirman: makhluk yang jika Aku mengambil darinya apa yang ia cintai ia berserah diri kepadaKu. Ia kembali bertanya: makhluk yang mana pula yang paling Engkau benci? Allah Swt berfirman: yang paling kubenci adalah hambaKu yang beristikharah kepadaKu dalam satu perkara kemudian ketika Aku menentukan kepadaNya suatu ketentuan ia marah kepada ketentuanKu.

Allah Swt berfirman dalam hadis qudsi: "Sesungguhnya Aku adalah Allah tidak ada Tuhan selain Aku".Barang Siapa yang tidak bersabar terhadap ujianKu dan tidak ridha terhadap ketentuanKu dan tidak bersyukur atas nikmatKu maka hendaklah ia mencari tuhan selainKu".

Abu Muhammad Sahal berkata: tingkat keyakinan seorang hamba bergantung kepada tingkat keridhaannya terhadap Allah Swt. Tingkat keridhaan seorang hamba bergantung kepada seberapa sering ia hidup bersama Allah Swt. Athiyah meriwayatkan dari Abu Sa id dari Rasulullah Saw bahwasanya Allah Swt dengan keagungan dan hukumNya menjadikan kelapangan dan kesenangan dalam keridhaan dan keyakinan dan menjadikan kesedihan dan kesusahan dalam keraguan dan keluhan. Di antara bentuk dari keridhaan ialah janganlah kamu mencela sedikitpun sesuatu yang mubah dan jangan pula menghinanya kalau memang itu sudah menjadi ketentuan Allah Swt, menyaksikan Sang Maha Pencipta dalam segala ciptaanNya melihat kepada keteraturan ciptaan dan hikmahNya jika hal tersebut tidak keluar dari kebiasaan akal dan adat.

Diceritakan dalam riwayat Israiliyat: bahwa Isa as bersama beberapa sahabatnya menghampiri bangkai anjing merekapun menutupi hidung mereka 
dan berkata: ah bauk sekali. Namun Isa as tidak menutup hidungnya namun berkata kepada para sahabatnya: alangkah putihnya giginya. Dengan sikapnya itu ia ingin mengajarkan kepada mereka untuk meninggalkan perbuatan gibah, mengajarkan kepada mereka untuk meninggalkan perbuatan mencela dan menghina segala sesuatunya. Bagaimana tidak karena ia melihat segala ciptaan berasal dari yang Maha Pencipta maka Ia mengalihkan pandangan mereka kepada makna sebenarnya.

Kami meriwayatkan sebuah hadis dari Rasulullah Saw: bahwasanya Rasulullah Saw tidak pernah mencela makanan sama sekali. Jikalau beliau menyukainya maka beliau memakannya dan jika tidak beliau meninggalkannya. Anas ra pernah berkata: saya melayani Rasulullah Saw selama 10 tahun lamanya. Tentunya setiap pelayan tidak dapat melakukan segala sesuatunya sesuai dengan kemauan tuannya. Namun beliau tidak pernah mengatakan kepadaku mengenai apa yang telah aku lakukan: kenapa kamu melakukannya? Juga mengenai sesuatu yang belum aku lakukan: kenapa kamu belum melakukannya? Beliau juga tidak pernah sekalipun berkata kepadaku mengenai sesuatu yang telah terjadi: seandainya hal itu tidak terjadi. Atau yang belum terjadi: seandainya ia terjadi. Beliau bersabda: seandainya Allah Swt menetapkan sesuatu maka Ia pasti terjadi.

Jadi pendidikan rohani di sini yang menguatkan hubungan dengan Allah adalah keridhoan itu membuat hubungan makin erat dengan Allah ditandai Allah Swt menyukai dan menyenangi si hamba.

\section{PENUTUP}

Berdasarkan pemaparan kajian di atas jelaslah bahwa pendidikan rohani adalah pendidikan yang menguatkan hubungan hamba dengan Tuhan yang dilakukan dengan menggiatkan ibadah kepada Allah Swt sehingga terjalin hubungan baik denganNya. Di antara upaya yang dapat dilakukan dan diperintahkan Allah untuk menguatkan hubungan tersebut adalah zikir, shalat, puasa, muraqabah, tazkiah dan ridha terhadap ketentuan Allah Swt. 


\section{DAFTAR PUSTAKA}

Abdul Halim Mahmud, Pendidikan Ruhani, Jakarta, Gema Insani Press, 2000

Abdur Rahman al-Burquni, al-Hadiyah as-Sa`idiyah fi al-Hikmahath-Thabi iyah, Cairo: al-Manar al-Islamiyah, $1222 \mathrm{H}$

Abu Thalib al-Makki, Qutul Qulub, Cairo, Dar al-Kutub al-Ilmiah, tt

Ahmad Bin Hanbal, Musnad juz.5, Cairo, Dar al-Kutub al-Ilmiah, 1995

Ahmad Mushtafa Al-Maraghi, Tafsir al-Maraghi Jilid.2, Cairo, Maktabah Ali alHalabi, 1946

Al-Jurjani, At-Ta 'rifat,Mesir,Musthafa al-Halabi, 1938

Al-Qusyairi, ar-Risalah al-Qusyairiyah, Beirut, Darul Khair, 1995

At-Tahanuwi, KasyfuIstilah al-Funun, Cairo, Dar al-Fikri, tt

At-Thabari, Tafsir at-Thabari Jilid.22 , Cairo, Dar Hajar, 2001

Aulia Reza Bastian, ReformasiPendidikan, Yogyakarta,LapperaPustakaUtama, 2002

Az-Zamakhsyari, Tafsir al-Kasysyaf, Beirut: Dar al-ma'rifah,1988

Dinas P \& K, KamusBesarBahasa Indonesia, Jakarta,BalaiPustaka, 2003

Ibnu al-Qayyim, Kitabar-Ruh, Beirut,dar al-Kutub al-Ilmiyah, 1982

Ibnu Katsir, Tafsir al-Quran Jilid. 11, Giza: Muassasah Qurthubah, 2000

Jaudah Muhammad Abul Yazid al-C, Bihar al-Wilayah al-Muhammadiyah Fi Manaqib A lam as-Shufiyah, Cairo, Dar al-gharib, 1998

Lois Ma 'luf, Al MunjidfilLughoh, Cairo: Maktabah Katolik, tt

M. Shodiq, Kamus Istilah Islam, Jakarta , C.V. Sienttarama, 1998

Samir Abdurrahman Rasyuni, Manhaj at-Tafsir al-Maudhu`i, Suria, Dar alMultaqa,2009 Team ilmuandanakademisiuniversitas di soviet, al-Mausu 'ah al-Falsafiyah, terjemahan. Samir Karam, Beirut: Dar at-Thali’ah, 1981 cetakan. IV.

Wahbah az-Zuhaili, at-tafsir al-Wazij, Beirut: Dar al-Fikr, tt

YahyaHuwaidi, Dirasat fi 'ilmi al-Kalamwa al-Falsafah al-Islamiyah, Mesir: Dar atsTsaqafah, 1980 
FITRAH Jurnal Kajian Ilmu-ilmu Keislaman

Vol. 02 No. 2 Desember 2016

Efek Menonton Acara di Televisi Terhadap Sosial Budaya

Masyarakat Muslim Kota Medan 